\title{
ANALISIS KOMUNIKASI PERSUASIF PADA AKUN INSTAGRAM FRELYNSHOP DALAM MENINGKATKAN BRAND IMAGE
}

\author{
Gisela Hennita ${ }^{1}$, Meisy Efna Prisylia ${ }^{2}$, Violita Saffira ${ }^{3}$ \\ Communication and Business Institute The London School of Public Relations Jakarta \\ Email: g.hennita@gmail.com
}

\begin{abstract}
ABSTRAK
Kehidupan masyarakat masa kini sudah semakin dipermudah seiring dengan hadirnya internet di Indonesia. Data Asosiasi Penyelenggara Jasa Internet Indonesia mengungkapkan bahwa jumlah pengguna internet di Indonesia sebesar 143,26 juta pada bulan Maret 2018. Media sosial merupakan media yang berkembang pada era komunikasi interaktif. Media sosial yang paling banyak digemari oleh masyarakat salah satunya adalah Instagram. Online shop merupakan strategi baru dalam perdagangan. Salah satu online shop yang menggunakan Instagram adalah Frelynshop yang di dirikan sejak tahun 2013 dan selalu melakukan komunikasi persuasif di instagramnya. Frelynshop menanamkan persepsi kepada konsumen bahwa Frelynshop merupakan online shop terbaik, terlengkap, dan ter-readystock. Meskipun sudah berjalan 5 tahun dan memiliki followers yang tergolong banyak di Instagram, Frelynshop masih mendapatkan komen atau review yang bersifat negatif dari para pembelinya. Berdasarkan ini, peneliti tertarik meneliti komunikasi persuasif yang dilakukan oleh Frelynshop dalam meningkatkan brand image di media sosial Instagram. Penelitian ini bertujuan untuk memahami komunikasi persuasif yang dilakukan oleh Frelynshop dalam meningkatkan brand image di media sosial Instagram. Dalam penelitian ini, peneliti menggunakan metode penelitian deskriptif dengan pendekatan kualitatif. Hasil penelitian dalam penelitian ini adalah dalam meningkatkan brand image, Frelynshop melakukan dengan konsisten untuk selalu memenuhi kebutuhan konsumennya dan melakukan beberapa kegiatan seperti giveaway, spam likes, QnA, dan live di Instagram secara konsisten sehingga mendapatkan respon yang positif dari konsumennya.
\end{abstract}

Kata Kunci: Brand Image, Komunikasi Persuasif, Media sosial

\section{ANALYSIS PERSUASIVE COMMUNICATION ON INSTAGRAM ACCOUNT FRELYNSHOP IN IMPROVING BRAND IMAGE}

\begin{abstract}
People's lives are more easier when the internet in Indonesia. The internet service data has revealed the amount of internet users in Indonesia 143,26 million in March 2018, social media is a medium media that develops on the interactive communication era. Instagram is the favorite social media. Online shops is a new strategy in marketing. One of the onlineshop that use Instagram is Frelynshop was fouded since 2013 and always do persuasive communication. Frelynshop instilled a perception to their customer is Frelynshop was the best shop, most complete, and most ready stock. Although five years of selling tumblr-tee and have many followers, Frelynshop still get a negative respon from their buyers. According to this, researchers are interested in persuasive communication has done by Frelynshop to raising the brand image. This study aims to understand the persuasive communication by Frelynshop in improving the brand image on social media Instagram. In this study, researchers used description research methods with the Qualitative approach. The result is for increase brand image, Frelynshop always builds communication for fulfilled consumer needs, by doing some activities like giveaway, spam likes, QnA, and live at Instagram so their get a positif respon from their consumers.
\end{abstract}

Keywords: Brand Image, Persuasive Communication, Social Media 
Korespondensi: Korespondensi: Gisela Hennita. Communication and Business Institute The London School of Public Relations Jakarta. Jl. K. H. Mas Mansyur No. kav. 35, RT12/RW11, Karet Tengsin, Tanah abang, Kota Jakarta Pusat 10220. No. Hp, WhatsApp: 0818972705 Email: g.hennita@gmail.com

\section{PENDAHULUAN}

Kehidupan masyarakat masa kini sudah semakin dipermudah seiring dengan hadirnya internet di Indonesia. Kegunaan internet dari waktu ke waktu juga sangat dibutuhkan oleh manusia. Inovasi yang terus dilakukan demi kemudahan masyarakat dalam berkomunikasi melalui internet hingga terciptalah telepon pintar (smartphone) (Sofia, 2017).

Smartphone memberikan beberapa layanan seperti SMS, telepon, E-mail, dan layanan internet. Indonesia menjadi salah satu pengguna internet terbesar di dunia. Data Asosiasi Penyelenggara Jasa Internet Indonesia (APJII) mengungkapkan bahwa jumlah pengguna internet di Indonesia sudah mencapai 143,26 juta pada bulan Maret 2018 (Soemartono, 2018, p.3). Sebesar 129,4 juta pengguna internet Indonesia untuk mengakses media sosial (Akmal, Mohammad \& Alfisyahr, 2018, p.92).

Kemajuan ini menunjukkan bahwa para pengguna smartphone selalu mengakses berbagai fitur salah satunya adalah sosial media. Media sosial merupakan media yang berkembang pada era komunikasi interaktif. Jadi dapat dikatakan bahwa masuknya media sosial membuat orang-orang yang mengakses bisa melakukan apa saja yang di inginkan seperti salah satunya adalah komunikasi.

Media sosial yang paling banyak digemari oleh masyarakat salah satunya adalah Instagam. Instagram merupakan sebuah aplikasi yang digunakan untuk berbagi foto, dan video dengan menggunakan berbagai fitur yang menarik serta menyebarluaskan di sosial media lainnya seperti twitter, facebook, dan lainnya. Josh Constine mengatakan bahwa pengguna Instagram mencapai 1 milliar pengguna pada bulan Juni 2018 (Constine, 2018).

Menurut Jessica Wade, sebagian besar pengguna Instagram pada tahun 2017 adalah perempuan berumur 18-29 tahun (Wade, 2017). Berdasarkan data diatas, dapat dikatakan bahwa Instagram banyak diminati oleh masyarakat Indonesia khususnya kaum perempuan. Sebagai salah satu media sosial yang paling digemari oleh masyarakat Indonesia, instagram menjadikan salah satu tempat pembisnis oleh para pembisnis online, karena selain dengan biayanya yang tergolong cepat dan murah, Instagram juga dapat mengjangkau konsumen yang tepat.

Dengan menggunakan fitur-fitur yang terdapat di Instagram membuat online shop dapat dengan mudah memberikan informasi mengenai produk-produk yang mereka jual. Sistem penjualan online ini lebih dikenal dengan istilah ecommerce (electronic commerce). E-commerce hanya perlu menggunakan internet untuk dapat melakukan sebuah transaksi, yang dapat dilakukan dimana saja. Dari e-commerce ini yang kemudian berkembang menjadi jual beli secara online (Irmawati, 2011).

Pada awal perkembangannya, para perusahaan perdagangan menjadikan online shop sebagai salah satu strategi baru dalam perdagangan di dunia maya. Kenyataannya, online shop yang 
dikelola oleh perseorangan lebih banyak dibandingkan dengan perusahaan dagang yang sudah ada (offline store). Online shop sendiri sudah ada sejak tahun 1994 (Sofia, 2017).

Online shop merupakan suatu proses jualbeli barang yang tidak harus bertatap muka dengan penjual atau pembeli secara langsung (Sofia, 2017). Jadi dapat disimpulkan bahwa pembeli hanya melihat dari foto-foto yang sudah di publish oleh penjual, ketika pembeli ingin membeli produk yang dituju dapat mengirimkan format order kepada penjual setelah itu penjual megirimkan nomor rekening untuk proses pembayaran, ketika sudah melakukan pembayaran penjual akan mengirimkan barang pembeli via ekspedisi.

Maraknya online shop di sosial media Instagram merupakan hasil dari maraknya fashion yang tengah digandrungi oleh masyarakat Indonesia. Online shop Instagram muncul dengan berbagai harga yang menarik dan sangat bersaing. Mereka bersaing dengan harga di toko pada umumnya maupun dengan online shop lainnya. Berbagai strategi juga dilakukan untuk memperoleh followers yang banyak sekaligus dengan pelanggan baru (Sofia, 2017).

Salah satu strateginya adalah dengan memberikan pengiriman gratis, ataupun memberikan potongan harga ketika membeli barang dalam jumlah yang banyak. Online Shop bukan sekedar dianggap sebagai pemilihan dalam berbelanja, melainkan menjadi bagian dari adanya perubahan sosial budaya dalam masyarakat (Sari, 2015, p. 208).

Tidak hanya itu dengan berbelanja online seorang konsumen akan mendapatkan sebuah pengalaman baru yang tidak bisa didapatkan pada saat berbelanja secara kovensional. Online shop yang yang menggunakan media sosial Instagram bernama Frelynshop. Frelynshop merupakan sebuah online shop yang berdiri sejak tahun 2013, yang didirikan oleh Ellyvia Jesslyn dan Alvina Elfreda.

Frelynshop sudah memiliki followers aktif di Instagram sebanyak 268K. Pada awal terbentuknya, Frelynshop hanya menjual tumblr tee (t-shirt) dengan warna hitam dan putih dengan harga Rp 30.000,-. T-shirt yang mereka jual dapat digunakan sehari-hari dalam berbagai motif yang menarik. Seiring berjalannya waktu Frelynshop sudah memiliki beberapa warna yang diantaranya hitam, maroon, navy, army, abu-abu, mustard, biru muda, pink, dan putih (Frelynshop, n.d.a).

Bahan yang digunakan oleh Frelynshop sendiri adalah cotton combat 30s (Frelynshop, n.d.a). Dari segi motif, warna dan jenis bahan yang digunakan menjadikan Frelynshop terlihat berbeda dari para pesaingnya. Tidak hanya itu Frelynshop juga memiliki pesaing yang juga memproduksi produk yang sama, sebut saja salah satunya adalah Sws_collection.

Sws_collection memiliki perbedaan yang terlihat yaitu mereka memilih warna yang cenderung lebih terang daripada Freynshop. Sws_collection juga terdapat beberapa macam warna yang diantaranya hitam, putih, abu-abu, kuning, oren, pink, army, maroon, navy, dan lainnya. Meskipun terdapat banyak pesaing yang menawarkan produk yang sama dengan memiliki keunikan tersendiri dari segi warna dan motif, namun Sws_collection memiliki target yang sama 
dengan Frelynshop yaitu anak muda (Sws_collection, n.d.).

Frelynshop menjual produknya hanya melalui sosial media seperti Instagram dan Shopee. Pada tampilan profile di Instagram Frelynshop akan terlihat foto-foto yang menunjukan warna serta motif-motif yang ditawarkan oleh Frelynshop dengan harga yang terjangkau. Tidak hanya konten (foto) yang ada pada profile Instagram, frelynshop juga sering kali menggunakan fitur igstory. Pada fitur tersebut Frelynshop menampilkan konten seperti video yang menunjukan gambaran produk tersebut ketika dipakai. Ada juga video yang berisikan informasi mengenai promo menarik yang ditawarkan oleh Frelynshop (Frelynshop, n.d.b).

Sosial media Instagram sebagai salah satu tempat yang digunakan oleh Frelynshop untuk melakukan komunikasi yang bersifat persuasif. Menurut K. Andeerson komunikasi persuasif didefinisikan sebagai perilaku komunikasi yang mempunyai tujuan yang mengubah keyakinan, sikap atau perilaku individu atau kelompok lain melalui transmisi beberapa pesan (Mulyana, 2005, p. 115). Pada kutipan di atas dapat dikatakan bahwa komunikasi persuasif dapat mengubah sikap, perilaku, maupun keyakinan seseorang atau kelompok terhadap nama suatu barang atau jasa.

Frelynshop mengkomunikasikan pesan mereka dan membangun brand image melalui akun Instagram. Frelynshop menciptakan brand image melalui konten-konten yang dibuat dengan kreatif dan menarik yang bertujuan untuk menanamkan persepsi kepada konsumen bahwa Frelynshop merupakan online shop terbaik, terlengkap, dan ter-readystock.
Persepsi inilah yang akan membentuk brand image dari Frelynshop. Citra merupakan suatu cara bagaimana orang lain memandang suatu perusahaan, seseorang, atau suatu komunitas tertentu. Dapat dikatakan bahwa citra dapat menggambarkan persepsi yang bisa sesuai dengan tujuan yang telah dibuat atau tidak. Citra yang terbentuk inilah yang mendasari dari keputusan pembelian hingga loyalitas merek (brand loyalty).

Citra terbentuk karena adanya pengalaman konsumen dalam berbelanja di frelynshop itu sendiri. Sampai saat ini Frelynshop sudah memiliki banyak customer baik pembeli baru maupun pembeli lama yang telah merepurchase produk mereka (Frelynshop, n.d.a). Customer-customer inilah yang turut membantu Frelynshop dalam memasarkan produk-produknya, salah satunya dengan menggunakan cara mulut ke mulut atau memberikan review kepada calon pembeli.

Kepuasan konsumen terhadap pelayanan yang diberikan, dan citra merek yang diciptakan oleh Frelynshop melalui Instagram turut menentukan bagaimana Frelynshop dapat bertahan selama 5 tahun. Frelynshop juga menjadi salah satu online shop yang memiliki customer yang cukup banyak. Meskipun sudah berjalan 5 tahun dan memiliki followers yang tergolong banyak di Instagram, Frelynshop masih mendapatkan komen atau review yang bersifat negatif dari para pembelinya, Komen atau review tersebut bisa saja memberikan dampak yang negatif juga bagi para pembacanya, dan Frelynshop itu sendiri (Frelynshop, n.d.a). 
Berdasarkan fenomena diatas, peneliti tertarik untuk meneliti bagaimana komunikasi persuasif yang dilakukan oleh Frelynshop dalam mengingkatkan brand image melalui media sosial Instagram, karena ditengah banyaknya persaingan diantara online shop yang menjual produk yang sama (para pesaing), Frelynshop terbilang sukses dalam membentuk citra merek dimata konsumen. Bedasarkan latar belakang yang telah diuraikan di atas, maka dapat dirumuskan masalahnya yaitu bagaimana komunikasi persuasif pada akun Instagram Frelynshop dalam meningkatkan brand image? Serta Penelitian ini bertujuan untuk memahami komunikasi persuasif yang dilakukan oleh Frelynshop dalam meningkatkan brand image di media sosial Instagram.

Menurut Devito (2009, p.410) persuasif adalah proses mempengaruhi sikap, keyakinan, nilai atau perilaku oranglain. Persuasif mampu menjadikan dunia lebih baik seperti layaknya persuader yang telah melakukan persuasi dari waktu ke waktu sehingga menjadikan keadaan yang lebih baik, akan tetapi fenomena ini tidak berhenti sampai disini, karena ada sisi gelap dari sebuah persuasif. Persuasif dapat digunakan menjadi suatu yang baik tetapi juga bisa menjadikan sesuatu yang tidak baik, dan itu semua kembali kepada pilihan kita. Tujuan komunikasi persuasif menurut Devito adalah untuk mempengaruhi orang lain dengan usaha mengubah keyakinan, nilai, dan sifat sasaran. Di dalam bukunya yang berjudul Komunikasi Antarmanusia ia juga menjelaskan bahwa pembicaraan persuasif mengetengahkan pembicaraan yang bersifat memperkuat, memberikan ilustrasi, dan memberikan informasi kepada seluruh khalayak, tetapi tujuan utamanya adalah mengubah sikap dan perilaku sehingga penggunaan fakta, pendapat, dan himbauan motivasional harus bersifat memperkuat tujuan persuasifnya (Devito, 2011, p.54).

Menurut Cialdini ada beberapa prinsip-prinsip dalam melakukan persuasif, yang diantaranya:

1. Reciprocation (Timbal Balik)

Cialdini mengungkapkan bahwa melalui prinsip ini, orang akan mau menolong dan memenuhi keinginan kita, apabila kita pernah memberikan atau memperlakukan mereka sama seperti yang kita ingin diperlakukan . Selanjutnya, memberikan senyuman sebagai tanda penghargaan, pujian, dan pemberian hadiah yang sewajarnya merupakan penerapan dari prinsip ini (Cialdini, 2009, p.13).

2. Commitment and Consistency (Komitmen dan konsistensi)

Prinsip ini mengungkapkan bahwa orangorang yang tidak suka mundur dari suatu kesepakatan. Mereka lebih memilih untuk melakukan sesuatu setelah menyetujui baik secara verbal maupun non verba. Menurut Cialdini, mereka juga lebih suka untuk mematuhi dan mengikuti suatu sikap, nilai, dan tindakan yang sudah ada sebelumnya (Cialdini, 2009, p.43).

\section{Social Proof (Bukti sosial)}

Ini merupakan suatu prinsip metode yang dapat digunakan untuk menentukan suatu perilaku yang benar dan untuk mengetahui apa yang orang lain pikir bahwa itu benar. Kebanyakan dari orang akan berfikir bahwa yang dilakukannya adalah sebuah tindakan yang benar berdasarkan dengan apa yang mereka lihat (Cialdini, 2009, p.87). 


\section{Liking (Kegemaran)}

Seseorang akan lebih memilih untuk setuju kepada orang-orang yang dikenal dan disukai (Cialdini, 2009, p. 126).

\section{Authority (otoritas)}

Ototritas juga dapat mempengaruhi orang lain, manusia juga tergerak kalau dipengaruhi oleh pihak yang banyak mempengaruhinya. Manusia bertindak dipengaruhi oleh otoritas yang mereka kagumi. (Cialdini, 2009, p. 157)

\section{Scarcity (Kelangkaan)}

Suatu keterbatasan menjadikan sesuatu yang penting. Yang dimana kita hanya memberikan sebuah manfaat kepada orang lain terlebih dahulu dengan cara menjelaskan kepada audiens, apa yang membuat rugi jika mereka tidak mendengarkan presentasi kita (Cialdini, 2009, p.178).

Menurut John December pengertian Computer Mediated Communication (CMC) adalah sebuah proses komunikasi manusia yang menggunakan media komputer dengan melibatkan orang, disituasikan dalam berbagai konteks, serta melibatkan proses-proses untuk membentuk media dengan tujuan yang beraneka ragam (Thurlow, Lengel \& Tomic, 2004, p.15). Dengan demikian, informasi yang disampaikan oleh komunikator yang melalui media komputer ini dapat diterima dan mampu mengubah perilaku si penerima pesan (receiver).

Dalam CMC (Darmawan, 2012, p. 135-136) terdapat beberapa dimensi-dimensi yang diantanya:

1. Dimensi Accessibility (Daya Jangkau atau akses informasi)
Dimensi ini mengindikasikan bahwa sebuah proses komunikasi yang bertujuan menyampaikan informasi melalui Computer Mediated Communication mencapai jangkauan yang sangat luas.

2. Dimensi Speed (Kecepatan informasi).

Dimensi kecepatan informasi ini mengindikasi bahwa proses penyampaian informasi oleh komunikator (sender) melalui Computer Mediated Communication dapat menunjukan kecepatan dalam penerimaannya oleh komunikan (receiver).

3. Dimensi Amount (Jumlah atau kuantitas Informasi)

Dimensi ini menunjukan bahwa informasi yang disampaikan oleh komunikator (sender) kepada komunikan (receiver) melalui CMC mampu memenuhi kebutuhan jumlah informasi yang diperlukan.

\section{Dimensi Cognitive Effectiveness} (Keefektifan Memperoleh Pengetahuan)

Dimensi ini menunjukan bahwa informasi yang disampaikan oleh komunikator (sender) kepada komunikan (receiver) melalui CMC mampu menanamkan dan memperkaya pengetahuan secara efektif mengenai informasi yang dibutuhkan.

5. Dimensi Relevance (Kesesuaian Informasi)

Dimensi ini menunjukan bahwa informasi yang disampaikan oleh komunikator (sender) kepada komunikan (receiver) melalui CMC mampu memenuhi tingkat kesesuaian serta kebutuhan.

\section{Dimensi Motivating (dari Informasi)}

Dimensi ini menunjukan bahwa informasi yang disampaikan oleh komunikator (sender) 
kepada komunikan (receiver) melalui CMC mampu menumbuhkan motivasi untuk memahami serta menerapkan.

Internet (interconnection networking) merupakan sebuah jaringan computer yang dapat menghubungkan suatu komputer dengan komputer lainnya, sehingga dapat berkomunikasi atau berbagi informasi tanpa melihat jenis komputer yang digunakan. Seperti yang suda diketahui, internet merupakan suatu bentuk konvergensi dari beberapa teknologi terdahulu, seperti komputer, televisi, radio, dan telepon (Bungin, 2006, p.135). Menurut Juju dan Sulianta (2010, p.7) karakteristik pada sosial media modern adalah sebagai berikut:

1. Transparansi: Segala tampak yang terbuka karena didalamnya yang terdapat elemen dan materinya memang ditujukan untuk konsumsi publik atau sekelompok orang.

2. Dialog dan komunikasi: Didalam suatu dialog akan terjalin suatu hubungan yang sepenuhnya berupa komunikasi, misalnya antara suatu brand dengan para konsumennya

3. Jejaring relasi: Hubungan antara elemenelemen penyusun akan terjalin dan juga terdapat relasi yang akan terbentuk antara individu atau kelompok suatu perwakilan yang dimotori oleh individu.

4. Multi opini: Setiap individu akan beraguman dan setiap orang memilik pandangan yang berbeda dan relatif, baik pandangan itu benar, salah atau berada dalam grey area, tergantung dalam wujud komunikasi sebagai medianya.

Semua orang pasti memiliki akun Isntagram, melalui Instagram juga kita dapat mengupload foto dan video yang kemudian kita membagikannya secara langsung kepada orang lain melalui internet yang menyediakan informasi secara cepat (Enterprise, 2012, p.2). Brand Image akan menjadi efektif jika dari sebuah merek adalah citranya. Seperti yang direfleksikan oleh asosiasi yang diakui oleh pelanggan (Keller, 2013, p. 379). Terdapat enam panduan umum dalam membangun citra. Keenam panduan tersebut mampu membangkitkan citra yang diungkapkan oleh Wasesa (2005, p.264-267) sebagai berikut:

1. Memetakan persepsi

Langkah yang pertama dalam membangkitkan citra adalah dengan mengadakan audit tentang citra organisasi tersebut di masyarakt. Dari hasil tersebut kemudian dipetakan posisi organisasi sebenarnya berada dimana di dalam persepi masyarakat. Sebelumnya ketahuilah terlebih dahulu dimana titik beratnya. Kemudian dari titik itu disinkrinasikan dengan visi dari manajemen. Dan di tahap inilah manajemen harus diyakinkan tentang perlunya program tersebut dan jelaskan kepada pihak manajemen mengenai keuntungan yang akan didapatkan apabila melaksanakan program PR tersebut.

2. Menyesuaikan dengan visi manajemen

Adanya perlu dilakukan kesesuaian dengan aktivitas top management. Inilah mengapa di tahap awal harus dapat diyakinkan manajemen yang mengetahui program yang akan dibuat terlebih dahulu. Kalau tidak maka program tersebut akan menjadi kontra produktif.

3. Pahami audiens

Audiens akan menjadi target sebelum membuat suatu program. Program dibuat harus sesuai dengan kebutuhan audiens, bukan 
sebaliknya. Kenali audiens terlebih dahulu , terutama kebutuhan komunitas mereka. Memahami kebutuhan audiens akan menentukan apakah program yang akan dijalankan berhasil atau tidak.

\section{Fokus}

Fokus terhadap titik pengembangan tertentu. Misalnya, apabila sebuah perusahaan atau komunitas fokus kepada pengembangan sosial maka setiap program dari perusahaan harus tetap fokus pada titik pengembangan yang sama yaitu sosial. Apabila suatu perusahaan sudah fokus, maka akan lebih mudah untuk menilai informasi dari sebuah program.

\section{Kreativitas}

Untuk melakukan komunikasi yang baik, diperlukan kreativitas. Kreativitas yang kita lakukan mengisyaratkan kreatif dalam hal yang sehubungan dengan program yang akan di jalankan.

\section{Konsistensi}

Program PR harus dijalankan secara konsisten, karena program tersebut menyangkit tentang sejauh mana kemampuan PR untuk mengubah suatu citra.

Dalam penelitian ini peneliti menggunakan teori Komunikasi persuasif dari prinsip-prinsip persuasif, Computer Mediated Communication (CMC) dari dimensi-dimensi CMC, Media sosial dari karakteristik media sosial, dan Brand Image dari enam titik pembangkit citra.

\section{METODE PENELITIAN}

Dalam penelitian ini peneliti menggunakan metode penelitian kualitatif deskriptif untuk menganalisa komunikasi persuasif yang dilakukan oleh Frelynshop sebagai online shop untuk meningkatkan brand image atau yang lebih dikenal dengan citra. Dalam penelitian ini pengumpulan data yang dilakukan oleh peneliti adalah menggunakan sumber data primer dan sekunder. peneliti megumpulkan data primer berupa wawancara semi terstruktur dengan tiga informan, sedangkan data sekunder yang akan dipakai dalam penelitian ini bersumber dari Jurnal dan bukubuku, Website, Internet dan media online.

Metode non-probability sampling dengan teknik quota sampling digunakan sebagai metode dan teknik pengambilan sampling pada penelitian ini. Metode non probability sampling merupakan metode pengambilan sampel yang tidak memberikan kesamaan peluang atau kesempatan kepada seluruh anggota populasi untuk dapat dipilih menjadi sampel sementara teknik quota sampling adalah teknik pengambilan sampel yang dilakukan dengan cara melakukan pengidentifikasian terhadap berbagai kriteria yang memiliki relevansi dengan hal yang diteliti serta mementukan jumlah sampel yang akan diambil (Neuman, 2014, p.249).

Berdasarkan metode pengambilan sampel tersebut maka narasumber dalam penelitian ini yaitu (1). Owner Frelynshop, Ellyvia Jesslyn; (2). Customer Frelynshop, Regina Octavia; dan (3). Customer Frelynshop, Cynthia Febriyanti. Dalam penelitian ini menggunakan triangulasi sumber sebagai teknik pemeriksaan kepercayaan. Dengan cara membandingkan data yang didapat melalui hasil wawancara kepada tiga narasumber yang berbeda.

Penelitian yang dilakukan pada bulan September 2018 hingga Juni 2019 ini 
menggunakan model analisa data Miles and Huberman, yang terdiri dari 1) reduksi data; 2) penyajian data; 3) penarikan kesimpulan atau verifikasi (Sugiyono, 2016, p.92).

\section{HASIL DAN PEMBAHASAN}

Penelitian ini dilakukan pada komunikasi persuasif yang dilakukan oleh Frelynshop dalam mengingkatkan brand image. Peneliti menggunakan wawancara semi terstruktur agar dapat menjawab pertanyaan penelitian yaitu bagaimana komunikasi persuasif pada akun Instagram Frelynshop dalam meningkatkan brand image. Informasi yang diperoleh dalam penelitian ini bersumber dari hasil wawancara semi terstruktur dengan informan. Peneliti mengajukan beberapa pertanyaan yang terkait dengan permasalahan yang diteliti dan telah disusun untuk diajukan kepada informan penelitian. Informasi yang diperoleh dibuat dalam bentuk transkrip, pertanyaan-pertanyaan yang bersifat penting dan kemudian di analisis. Pada saat sekarang ini, dunia internet dijadikan peluang dalam dunia perdagangan.

Berdasarkan wawancara dengan Ellyvia Jesslyn selaku owner dari Frelynshop pada tanggal 29 Mei 2019, dapat dilihat bahwa Frelynshop sudah melakukan semua prinsip-prinsip komunikasi persuasif. Pertama yaitu timbal balik yang dimana mereka selaku online shop selalu memberikan respon terbaik kepada konsumennya ketika mereka bertanya melalui chat. Prinsip kedua yaitu komitmen dan konsisten, yang dimana Frelynshop selalu memposting hanya memposting tiga foto disetiap harinya dan memberikan konten lain agar konsumennya meresa owner Frelynshop adalah teman mereka juga. Pada prinsip yang ketiga yaitu bukti sosial, dimana Frelynshop ini sudah menjadi online shop yang dipertimbangkan oleh para konsumennya karena telah memiliki followers yang tergolong banyak di Instagram.

Setiap orang pasti memiliki sebuah kegemaran, yang dimana biasanya manusia akan menyukai hal yang sama seperti mereka. Dapat dilihat bahwa Frelynshop menjual dan mempresentasikannya secara menarik kepada para konsumennya sehingga mereka merasa puas dan cocok dengan Frelynshop. Secara tidak langsung juga mereka telah memiliki otoritas yang dimana mereka dapat membuat para konsumennya percaya dan membeli produk mereka baik dengan kuantitas yang sedikit maupun banyak. Keunikan yang dimiliki oleh Frelynshop juga yang membuat para konsumennya tertarik untuk membeli produk yang mereka tawarkan.

Penggunaan media sosial seperti Instagram sebagai tempat berdagang merupakan salah satu peluang yang terbaik, yang dimana informasi yang mereka berikan dapat diakses dimana saja dan kapan saja. Sama halnya dengan Frelynshop yang dimana mereka menggunakan media sosial Instagram sehingga konsumennya dapat mendapatkan informasi dari berbagai daerah. Frelynshop sendiri pernah melakukan riset yang dimana konsumen mereka terdapat dari beberapa daerah yaitu Kalimantan, Sulawesi, NTT, dan NTB.

Jumlah followers yang banyak juga dapa memberikan kecepatan informasi yang cepat dan tepat sasaran sehingga mudah ditangkap dan dimengerti oleh para konsumennya. Ketika seorang 
online shop memberikan jumlah informasi yang banyak hal tersebut dapat menguntungkan pihak konsumen karena mendapatkan informasi yang cukup dan diperlukan untuk mereka serta mereka juga dapat memperoleh informasi dari caption Instagram yang dibuat oleh Frelynshop disetiap post yang mereka buat. Dengan memberikan informasi yang sesuai kepada konsumennya, mereka akan merasa puas ketika berbelanja dengan online shop tersebut karena mereka merasa tidak dibohongi oleh tokonya. Sama seperti Frelynshop yang selalu memberikan informasi yang sesuai dengan apa yang diperlukan oleh konsumennya.

Setiap online shop secara tidak langsung pasti akan memberikan motivasi kepada konsumennya untuk membeli produk mereka. Seperti Frelynshop yang memberikan model-model yang up to date untuk para konsumennya. Media sosial memang bersifat terbuka bagi para penggunanya, tetapi memang masing-masing bisa memilih apa yang mau mereka bagikan dan apa yang tidak ingin dibagikan kepada publik. Disini Frelynshop sudah menjadi online shop memiliki banyak followers yang ini mendapatkan informasi mengenai semua produk apapun yang mereka tawarkan. Sehingga sejalan dengan yang sudah ia katakan bahwa instagramnya bersifat terbuka.

Online shop harus bisa menjalin komunikasi yang baik dengan para konsumennya. komunikasi yang terjalin antara pembeli dan penjual harus berjalan dengan baik, sehingga timbulnya rasa percaya pembeli terhadap online shop, sehingga dapat memudahkan online shop untuk mempengaruhi followersnya untuk membeli produknya. Frelynshop sendiri sudah melakukan kegiatan dialog dan komunikasi dengan baik.

Hubungan antara elemen-elemen penyusun akan terjalin dan juga relasi ini akan terbentuk antara individu atau kelompok suatu perwakilan yang dimotori oleh individu (Juju \& Sulianta, 2010, p.7). Hal ini sejalan dengan Frelynshop yang memiliki jejarng relasi atau menambah banyak teman baru maupun rekan kerja, tentu akan semakin membuatnya dikenal lebih banyak orang, sehingga dalam melakukan persuasif di media sosial pun bisa mendapatkan pengakuan lebih dari para followersnya.

Multi opini merupakan karakteristik terakhir pada media sosial. Setiap individu akan beragumen dan setiap orang memiliki pandangan yang berbeda dan relatif, baik pandangan itu benar, salah atau berada pada grey area, tergantung dalam wujud komunikasi sebagai medianya. Hal ini dapat dilihat dari bagaimana seorang online shop menanggapi sebuah argument yang muncul, karena di dalam media sosial memberikan kebebasan kepada pemilik akun untuk beragumen dan melakukan apa saja, oleh karena itu, sikap dari online shop itu sendiri lah yang menentukan hasilnya. Frelynshop sendiri terkadang mendapatkan komentar yang positif dan negatif. Dapat dilihat dari pernyataan owner Frelynshop yang mengatakan bahwa:

"Kalau komen yang positif ketika aku live sih biasanya banyak yang bilang kalau bajunya bagus, sudah sering beli disini gitu-gitu sih. Kalau hate komen sih biasanya paling karna itu tadi sih yang tidak sampai-sampai. Kalau komennya lovely, paling aku bales terima kasih. Lebih banyak komen-komen yang positif sih dari pada yang 
negatif." (Ellyvia Jesslyn, komunikasi pribadi, 29 Mei 2019)

Dalam meningkatkan brand image, sebuah brand harus bisa memetakan persepsi. Dengan mengadakan audit tentang citra organisasi tersebut di masyarakat. Dari hasil tersebut kemudian dipetakan posisi berada dimana dalam persepsi masyarakat. Kemudian dari titik tersebut disinkronasikan dengan visi dari manajemen. Dan di tahap inilah manajemen harus meyakinkan tentang perlunya program tersebut dan jelaskan kepada pihak manajemen mengenai keuntungan yang akan didapat apabila melaksanakan program tersebut (Wasesa, 2005, p.264). Frelynshop sudah memetakan persepsi kepada konsumennya dengan cara menjadi "teman" untuk para followers dan pembelinya serta memberikan kualitas yang terbaik dengann harga yang terjangkau.

Mereka juga melakukan kegiatan yang sesuai dengan visi dan misi mereka sehingga banyak followers mereka yang yakin dan percaya kepada Frelynshop dan membeli produk yang mereka jual. Hal tersebut sesuai dengan enam titik pembangkit citra yang diungkapkan oleh Wasesa bahwa adanya kesesuaian dengan aktivitas dan harus dapat diyakinkan manajemen mengetahui program yang akan dibuatnya terlebih dahulu. Kalau tidak program tersebut akan menjadi kontra produktif (2005, p. 265).

Pahami audiens merupakan langkah ketiga pembangkit citra. Audiens akan menjadi target sebelum membuat suatu program. Kenali audiens terlebih dahulu, terutama kebutuhan komunitas mereka. Memahami kebutuhan audiens akan menentukan apakah program yang akan dijalankan berhasil atau tidak. Frelynshop sudah memenuhi kebutuhan konsumennya dan dengan mendengarkan saran-saran dari konsumen ia jadi tahu apa yang diinginkan oleh para followersnya. Sejak awal Frelynshop juga fokus terhadap apa yang mereka jual. Mereka hanya menjual kaos dengan model yang up to date dan tidak menjual produk lainnya.

Sebagai sebuah online shop harus bisa kreatif. Frelynshop sendiri telah melakukan komunikasi yang kreatif kepada para followersnya dengan cara membuat giveaway maupun spam likes serta menggunakan fitur-fitur yang ada di Instagram untuk menambah kreativitas dalam berkomunikasi. Hal tersebut sesuai dengan enam titik pembangkit citra yaitu kreativitas yang di kemukakan oleh Wasesa yaitu untuk melakukan komunikasi yang baik, diperlukan kreativitas. Kreativitas yang kita lakukan mengisyaratkan kreatif dalam hal yang sehubungan dengan program yang akan dijalankan (2005, p. 266). Frelynshop sudah konsisten dalam memberikan informasi dan dalam mengadakan kegiatan seperti spam likes dan giveaway yang membuat followersnya tidak hanya sekedar memfollow Frelynshop ketika membutuhkan kaos saja.

Menurut hasil penelitian yang telah dianalisis, terdapat enam prinsip komunikasi persuasif yang diungkapkan oleh Cialdini dan digunakan sebagai fokus dalam penelitian ini yaitu prinsip timbal balik, komitmen dan konsistensi, bukti sosial, kegemaran, otoritas, dan kelangkaan. Seluruh prinsip ini telah dijabarkan di atas dan memperoleh hasil bahwa komunikasi persuasif yang dilakukan Frelynshop sesuai dengan prinsip-prinsip yang 
telah dikemukakan. Selain itu juga menggunakan elemen dari konsep CMC, Media sosial, dan Brand Image.

Prinsip yang pertama adalah timbal balik ditemukan bahwa salah satu cara yang cukup efektif menjaga hubungan timbal balik dengan cara membalas komen-komen dan direct message. Dengan adanya hubungan timbal balik ini membuat komunikasi persuasif dapat dilaksanakan dengan mudah karena sudah memiliki hubungan yang baik dengan para followersnya.

Kemudian ditemukan juga apabila online shop dapat selalu konsisten dan komitmen dengan apa yang mereka lakukan seperti mempost konten sesuai konsisten tentu akan menambah rasa kepercayaan dari para followersnya karena tidak berubah-ubah, terus mengembangkan satu hal yang menjadi fokusnya. Kemudian dengan cara memiliki banyak followers di Instagram juga akan membuat online shop tersebut mendapatkan bukti sosial atau kepercayaan dari orang lain.

Ditemukan juga bahwa secara tidak langsung online shop memiliki otoritas dalam mempengaruhi followersnya tanpa mereka sadari. Karena tanpa sadar hubungan ini sudah membangun kepercayaan antara Frelynshop itu sendiri dengan para pembelinya maupun followersnya. Jadi followers tersebut tanpa sadar sudah menjadi pembeli mereka. Kemudian ditemukan bahwa prinsip kelangkaan bahwa Frelynshop memiliki keunikan yaitu sebuah online shop yang selalu memperlihatkan kaosnya dengan cara on-model sehingga dapat mempengaruhi orang untuk menyukai dan membelinya.
Adapun cara-cara yang dilakukan Frelynshop dalam mempengaruhi followersnya adalah dengan selalu membuat konten Instagram yang menarik dalam feedsnya seperti konsep keluarga dengan menggunakan produk mereka, memberikan informasi yang lengkap dan jelas mengenai produk sehingga menghasilkan konten Instagram yang menarik.

Frelynshop juga melakukan kegiatan giveaway, spam likes, QnA, dan live di Instagram. Mereka rutin melakukan hal tersebut untuk mengetahui apa yang di inginkan oleh konsumennya dan meskipun followers mereka sudah banyak, mereka sangat konsisten dalam melakukan kegiatan tersebut sehingga mereka mendapatkan banyak followers maupun pembeli baru. Banyak dari followers maupun pembeli mereka yang telah membeli, memberikan respon yang bersifat positif, sehingga hal tersebut dapat meningkatkan brand image Frelynshop itu sendiri.

\section{SIMPULAN}

Berdasarkan analisis serta pembahasan dari hasil penelitian mengenai komunikasi persuasif Frelynshop dalam meningkatkan brand image di Instagram, maka peneliti dapat menyimpulkan bahwa Frelynshop sudah melakukan komunikasi persuasif dengan cara selalu konsisten dalam memposting foto di feeds, sehingga cara Frelynshop mempersuasi para followersnya dengan cara non-verbal yang ditujukan dari konten Instagram yang berupa foto, caption, dan igstory yang berupa video, agar dapat mempengaruhi para followersnya untuk membeli produk mereka. Hal ini dapat dibuktikan oleh jawaban informan yang membeli produk mereka. Dengan mendapatkan 
banyak followers merupakan suatu keuntungan bagi Frelynshop karena mendapatkan peningkatan pada pembelian produk dan memiliki followers yang aktif. Meskipun sudah memiliki banyak followers dan dalam rangka meningkatkan brand image, Frelynshop tetap melakukan kegiatan sesuai dengan visi dan misi mereka, selalu berusaha untuk memenuhi kebutuhan konsumennya, dan juga mengadakan kegiatan giveaway maupun spam likes, QnA, dan live di Instagram secara konsisten sehingga mendapatkan respon yang positif dari konsumennya.

\section{DAFTAR PUSTAKA}

Augustin, C. (2015). Analisis Pengaruh Core Service Buku

Bungin, B. (2006). Sosiologi komunikasi: teori, paradigma dan diskursus teknologi komunikasi di masyarakat Jakarta, Indonesia: Kencana Prenada Media.

Cialdini, R. B. (2009). The psychology

influence of persuasion revised edition. New York, NY: First Harper Collins.

Darmawan, D. (2012). Pendidikan teknologi informasi, teori dan aplikasi. Bandung, Indonesia: PT. Remaja Rosdakarya.

Devito, A. J. (2009). Eleventh edition human communication. New York, NY: Pearson International Edition.

Devito, A. J. (2011). Komunikasi antarmanusia. Tangerang Selatan, Indonesia: Karisma Publishing Group.

Enterprise, J. (2012). Instagram untuk fotografi digital dan bisnis kreatif. Jakarta, Indonesia: PT Elex Media Komputindo.

Juju \& Sulianta, F. (2010). Branding promotion with social networks. Jakarta, Indonesia: PT. Elex Media Komputindo.

Keller, K. L. (2013). Strategic brand management: building, measuring, and managing brand equity fourth edition. London, England: Pearson Education Limited.
Mulyana, D. (2005). Ilmu Komunikasi: Suatu Pengantar. Bandung, Indonesia: PT. Remaja Rosdakarya.

Neuman, W. L. (2014). Social Research

Methods: Qualitative And Quantitative Approaches.(Eds 7). Harlow, United Kingdom: Pearson Education Limited.

Sugiyono (2016). Metode penelitian kualitatif.

Bandung, Indonesia: CV Alfabeta.

Thurlow, Lengel, \& Tomic, A. (2004). Computer mediated communication. Social interaction and the internet. London, England: Southwark London Printed.

Wasesa, S. A. (2005). Strategi public relations. Jakarta, Indonesia: PT. Gramedia Pustaka Utama.

Jurnal Online

Akmal, Mohammad \& Alfisyahr, R.(2018).

Analisis Dampak Pemasaran Di Media Sosial Online Terhadap Citra Merek, Minat Beli Konsumen, dan Net Promoter Score. Jurnal Administrasi Bisnis (JAB), Volume 55, Nomor1. Diperoleh dari https://administrasibisnis.studentjournal.ub.ac.id/i ndex.php/jab/article/v iew/2244

Irmawati, D. (2011). Pemanfaatan e-commerce dalam dunia bisnis. Jurnal Ilmiah Orasi Bisnis, Edisi ke VI. Diperoleh dari https://www.academia.edu/4911623/PEMANFAA TAN_E-

Sari, C. A. (2015). Perilaku berbelanja online di kalangan mahasiswi antropologi Universitas Airlangga. Jurnal AntroUnairdotNet, Volume IV, Nomor 2. Diperoleh dari https://journal.unair.ac.id/download-

fullpapers-auna97cbdaabbfull.pdf

Sofia, M. (2017). Pengaruh Instagram Sebagai

Media Online Shopping Fashion terhadap Perilaku Konsumtif Mahasiswi Fakultas Ilmu Sosial dan Ilmu Politik Universitas Riau. JOM FISIP, Volume 4, Nomor 1. Diperoleh dari https://media.neliti.com/media/publications/11844 0-ID-none.pdf

Website

Constine, J. (2018). Instagram hits 1 billion monthly users, up from $800 \mathrm{M}$ in September. Diperoleh pada 20 Oktober 2018, dari website techcrunch: https://techcrunch.com/2018/06/20/instagram-1billion-users/ 
Frelynshop [@frelynshop]. (n.d.a). Post [Instagram profile]. Diperoleh pada 14 Juni 2019, dari https://www.instagram.com/frelynshop/?hl=id

Frelynshop [@frelynshop]. (n.d.b). Tagged

[Instagram profile]. Diperoleh pada 14 Juni 2019, dari https://www.instagram.com/frelynshop/?hl=id

Soemartono, H. K. (2018). Data Asosiasi

Penyelenggara Jasa Internet Indonesia Maret 2018. Diperoleh pada 10 Juni 2019, dari website apjii: https://apjii.or.id/content/read/104/348/BULETIN -APJII-EDISI-22--- Maret- 2018

Sws collection [@sws_collection]. (n.d.). Post [Instagram profile]. Diperoleh pada 14 Juni 2019, dari https://www.instagram.com/sws_collection/?hl=id

Wade, J. (2018). Instagram statistic 2017. Diperoleh pada 20 Oktober 2018, dari https://www.smartinsights.com/social-mediamarketing/instagram-marketing/instagramstatistics/

Laporan wawancara

Ellyvia, J. (2019, 29 Mei). Personal Interview. 